DOE/NASA/51040-36

NASA-TM-82783 19820010817

NASA TM-82783

\title{
Experimental Study of an Integral Catalytic Combustor- Heat Exchanger for Stirling Engines
}

Daniel L. Bulzan

National Aeronautics and Space Administration

Lewis Research Center

Work performed for

U.S. DEPARTMENT OF ENERGY

Conservation and Renewable Energy Office of Vehicle and Engine R\&D

Prepared for

LIBRARY GQPY

$\operatorname{liAR} 91982$
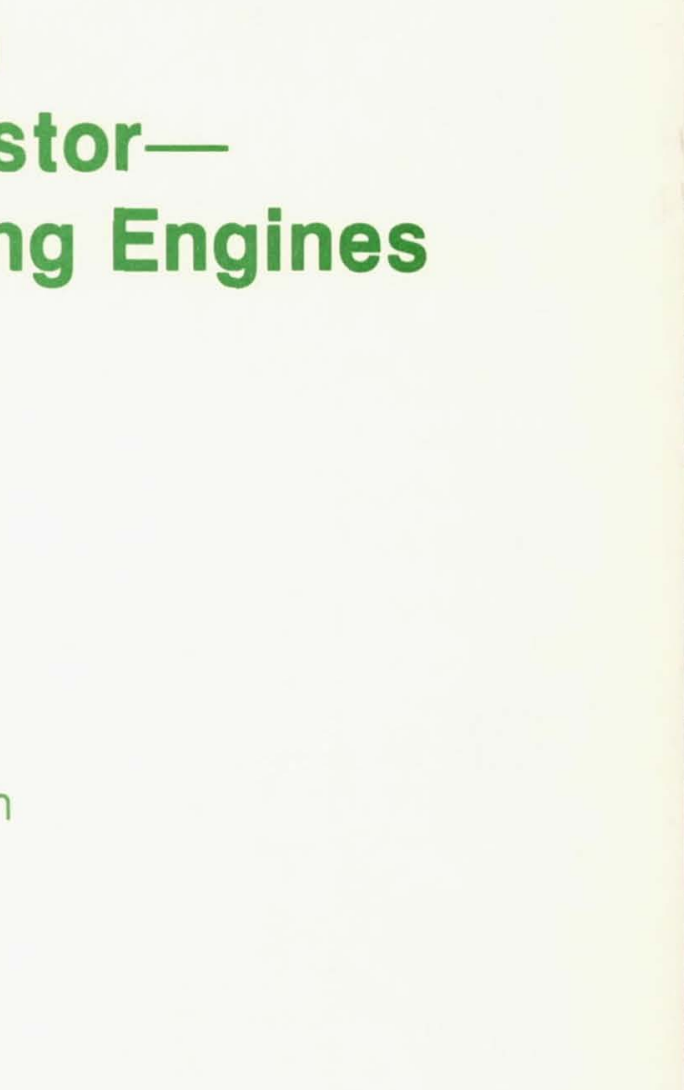

1982 International Congress and Exposition sponsored by the Society of Automotive Engineers

Detroit, Michigan, February 22-26, 1982 


\section{NOTICE}

This report was prepared to document work sponsored by the United States Government Neither the United States nor its agent. the United States Department of Energy. nor any Federal employees. nor any of their contractors. subcontractors or their employees. makes any warranty, express or implied, or assumes any legal liability or responsibility for the accuracy, completeness, or usefulness of any information. apparatus. product or process disclosed. or represents that its use would not infringe privately owned rights 
DOE/NASA/51040-36

NASA TM-82783

\section{Experimental Study of an Integral Catalytic Combustor- Heat Exchanger for Stirling Engines}

Daniel L. Bulzan

National Aeronautics and Space Administration

Lewis Research Center

Cleveland, Ohio 44135

Work performed for

U.S. DEPARTMENT OF ENERGY

Conservation and Renewable Energy

Office of Vehicle and Engine R\&D

Washington, D.C. 20545

Under Interagency Agreement DE-AI01-77CS51040

1982 International Congress and Exposition sponsored by the Society of Automotive Engineers Detroit, Michigan, February 22-26, 1982 
ABSTRACT

An experimental study was conducted to determine the feasibility of using catalytic combustion with heat removal for the Stirling engine to reduce exhaust emissions and also improve heat transfer to the working fluid. The study was conducted using spaced parallel plates. An internally air-cooled heat exchanger was placed between two noble metal catalytic plates. A preheated fuel-air mixture passed between the plates and reacted on the surface of the catalyzed plates. Heat was removed from the catalytic surface by radiation and convection to the air-cooled heat exchangers to control temperature and minimize thermal $\mathrm{NO}_{\mathrm{x}}$ emissions. The study was conducted at in let combustion a ir temperatures from 850 to $900 \mathrm{~K}$, in let velocities of about $10 \mathrm{~m} / \mathrm{s}$, equivalence ratios from 0.5 to 0.9 , and pressures from $1.3 \times 10^{5}$ to $2.0 \times 10^{5} \mathrm{~Pa}$. Propane fuel was used for a 11 testing. Combustion efficiencies greater than 99.5 percent were measured. $\mathrm{NO}_{\mathrm{x}}$ emissions ranged from 1.7 to $3.3 \mathrm{~g} \mathrm{NO}_{2} / \mathrm{kg}$ fuel. The results demonstrate the feasibility of the concept and indicate that further investigation of the concept is warranted. 
AS PART OF THE STIRLING ENGINE Highway Vehicle Systems Project, Lewis Research Center is currently considering catalytic combustion as a potential low-emissions concept for the Stirling engine. The present study was performed to evaluate one catalytic combustor configuration at Stirling engine conditions to determine if catalytic combustion might offer emission or heat transfer advantages over conventional combustion systems.

A cross-section of the P40 Stirling engine is shown in Fig. 1(a). The engine operates on the thermodynamic cycle of isothermal compression and expansion and constant volume heating and cooling. The working fluid, usually hydrogen, is heated, cooled, expanded, and compressed at the appropriate times in the cylinders to move the pistons and drive the engine. The working fluid is moved from the hot end of the cylinder, through the heater tubes, where heat is received from the combustion products, into the regenerator, where heat is given up and stored, then through a cooler, where it is cooled, and finally enters the cold end or lower portion of the cylinder. As the piston moves down, the working fluid is pumped back through the cooler, regenerator and heater tubes into the hot end of the engine where it expands and pushes the piston down. As the piston moves up, the cycle is repeated. A complete description of the Stirling cycle can be found in Ref. 1. A schematic diagram of the conventional combustion system used for the P40 Stirling engine is presented in Fig. 1(b) (2). Average temperatures are shown in the figure. Combustion air is supplied by a blower. The air passes through a preheater where it is heated to approximately $1000 \mathrm{~K}$ and then enters the combustor. Fuel is injected through an air-assist fuel injector and combustion takes place at equivalence ratios ranging from 0.6 to 0.9 . The combustion products pass over two banks of heater tubes through which the working fluid is flowing. Heater tube wall temperature is held constant at about $1000 \mathrm{~K}$. After passing over the heater tubes, the combustion products exit through the preheater where their sensible heat is used to preheat the inlet

ॠNumbers in parentheses designate References at end of paper. 
air. The Stirling engine is inherently a producer of high $\mathrm{NO}_{x}$ emissions because of the near stoichiometric conditions in the combustor. To meet automotive NOx standards, exhaust gas recirculation is used (2-4). As shown in Fig. 1(b), it ranges from 30 to 90 percent of the inlet air flowrate. $\mathrm{Higher}$ engine cycle efficiencies require higher working fluid temperatures (1). This may necessitate increased levels of Exhaust $\mathrm{Gas}$ Recirculation in order to meet $\mathrm{NO}_{x}$ emission standards.

Catalytic combustion is being considered as an alternative to the previously described conventional system. Catalytic combustion with heat removal has the potential of combining the combustor and heater tubes into an integral unit. Catalytic combustion with heat removal may offer several advantages over a conventional combustion system. Catalytic combustion is capable of reacting fuel-air mixtures at lower combustion temperatures than would otherwise be possible (5-6). With an integral catalytic combustor/heat exchanger, heat can be removed from the system as combustion is occurring which will reduce flame temperatures and minimize the formation of thermal $\mathrm{NO}_{\mathrm{x}}$ emissions. Catalytic combustion with heat removal has been successfully tested for application to watertube boilers (7). A configuration utilizing two concentric tubes with air cooling of the center tube and combustion of a fuel-air mixture in the annulus has also been successfully tested. Combustion efficiencies greater than 99.5 percent and $\mathrm{NO}_{\mathrm{x}}$ emissions less than 2 parts per million were obtained (8)

For the present study, an experimental evaluation was conducted for a configuration that used the radiation-cooled concept of Ref. 8. It consisted of a series of spaced parallel plates. Each plate was $10.2 \mathrm{~cm}$ long and $10.2 \mathrm{~cm}$ high. An air-cooled heat exchanger plate was placed between two catalyst coated plates. Tests were conducted at inlet a ir temperatures up to $900 \mathrm{~K}$, pressures of $1.3 \times 10^{5}$ to $2 \times 10^{5} \mathrm{~Pa}$, and a range of equivalence ratios from 0.5 to 0.9 . Propane fuel was used for all tests. Inlet and exit temperature of the cooling air and combustion mixture were measured. Heat exchanger plate wall temperatures were also measured. Combustion products were sampled and concentra- 
tions of $\mathrm{CO}_{2}, \mathrm{CO}, \mathrm{NO}_{x}$, and unburned

hydrocarbons were measured.

\section{EXPERIMENTAL DETAILS}

The test section simulated a segment of a possible Stirling engine heater head design. Figure 2(a) is a schematic drawing of the test rig used for this study. The test section was constructed of $0.64 \mathrm{~cm}$ thick stainless steel plate welded into a rectangular, 12.4 by $15.2 \mathrm{~cm}$ inside dimensions, test section. The test section was internally insulated with castable insulation to minimize heat losses. Inlet combustion air was indirectly preheated and entered the test section at temperatures up to $900 \mathrm{~K}$. Inlet air temperature was measured with a single Chromel/Alumel thermocouple. located at the centerline $6.35 \mathrm{~cm}$ upstream of the catalytic and heat exchanger plates. All temperatures were measured with Chromel/Alumel thermocouples. The combustion air flowed through two mullite honeycomb monolith flow straightness. Both monoliths had $0.318 \mathrm{~cm}$ round holes. For the second monolith placed directly upstream of the catalytic and heat exchanger plates, all holes were blocked with ceramic cement except those alligned with the rectangular passages between the plates.

Gaseous propane fuel was injected through sixteen, $0.03 \mathrm{~cm}$ inside diameter tubes which were placed inside the open passages of the flow straightener and equally spaced. The tubes were placed in two rows of 8 tubes to inject fuel into each of two rectangular passages. All fuel tubes were the same length, $25.4 \mathrm{~cm}$, to provide equal flowrates through each tube and obtain a uniform fuelair mixture for the catalytic plates.

The catalytic and heat exchanger plates were located directly downstream of the fuel injector as shown in Fig. 2(a). Figure 2(b) is a drawing of the plate configuration tested. The configuration consisted of three spaced parallel plates. A heat exchanger plate was placed btween two catalytic plates. Plate spacing of $0.318 \mathrm{~cm}$ was maintained by ceramic rods inserted between the plates. The preheated fuel-air mixture flowed through the two passages between the plates and reacted on the surface of the catalytic plates. For some cases, combustion gas temperature was measured at two axial 
locations in each passage. Castable insulation, not shown in Fig. 2(b), completely encased the plate assembly to insulate and also prevent bypassing of the flow around the plates.

Figure 3 is a drawing of the heat exchanger plate. It was $0.64 \mathrm{~cm}$ thick. It was internally air-cooled with the cooling air making 8 passes through the plate. Cooling air passages with rectangular cross sections of 0.91 by $0.32 \mathrm{~cm}$. were machined in the plate. The heat exchanger plate was constructed of Hastelloy-X. Cooling air entered and exited the heat exchanger plate as shown in Fig. 3. Wall temperatures were measured with shielded thermocouples attached to the outside walls.

The catalytic plates were made from sintered silicon carbide with an alumina washcoat to which a noble metal catalyst was applied. Catalytic plate length and height was the same as the heat exchanger plate, 10.2 by $10.2 \mathrm{~cm}$. Plate thickness was $0.318 \mathrm{~cm}$.

Combustion products exit temperature was measured $3.5 \mathrm{~cm}$ downstream of the catalytic and heat exchanger plates with two thermocouples located approximately $0.2 \mathrm{~cm}$ from each side wall. A water-cooled stainless steel gas sampling probe was used to obtain a continuous sample for emissions measurements $10.17 \mathrm{~cm}$ downstream of the plates at the rig centerline. The gas sample line was heated to prevent unburned hydrocarbons from condensing. Concentrations of $\mathrm{CO}$ and $\mathrm{CO}_{2}$ were measured with nondispersive infrared analyzers, unburned hydrocarbons with a flame ionization detector and nitrogen oxides (total $\mathrm{NO}+\mathrm{NO}_{2}$ ) with a chemiluminescent analyzer. A manual back pressure valve was used to control rig pressure. Combustion and cooling air flowrates were measured with calibrated $0.254 \mathrm{~cm}$ diameter orifices. Gaseous propane fuel flowrates were measured with a calibrated $0.051 \mathrm{~cm}$ diameter orifice.

\section{MEASUREMENTS AND COMPUTATIONS}

INLET VELOCITY - Inlet velocity was calculated using the air and fuel mass flowrates, inlet air temperature, inlet pressure, and the cross-sectional flow area between the plates. 
EMISSION INDEX - Emissions were measured as concentrations in ppm by volume, corrected for water of combustion, and converted to emission indices using the expressions in Ref. 9.

COMBUSTION EFFICIENCY - Combustion efficiency was calculated from the expression,

$$
\begin{aligned}
E F F=100 & -0.1\left[E \cdot I_{H C}-E \cdot I \cdot H C, E Q\right] \\
& -0.1\left[\frac{H V_{C O}}{H V_{F U E L}}\right][E \cdot I \cdot C O-E . I \cdot C O, E Q]
\end{aligned}
$$

where

$$
\begin{aligned}
& \text { EFF combustion efficiency, percent } \\
& \text { E.I.x emission index of specie } x \text {, } \\
& \mathrm{gx} / \mathrm{kg} \text { fuel } \\
& H V_{X} \quad \text { net heating value of specie } X, J / k g
\end{aligned}
$$

Equilibriúm values, E.I.x, eq at the average measured exit temperature were calculated using the computer program of Ref. 10.

HEAT FLUX - Heat flux to the cooling air was calculated using the measured cooling air mass flowrate, the temperature difference between the inlet and exit, and an average constant pressure specific heat at the average cooling air temperature.

\section{RESULTS AND DISCUSSION}

EMISSIONS - The effect of equivalence ratio on $\mathrm{NO}_{X}$ emssions is presented in Fig. 4. NOX emissions are presented as an emission index, $\mathrm{g} \mathrm{N} \mathrm{N}_{2} / \mathrm{kg}$ fuel for equivalence ratios ranging from 0.55 to 0.90 . $\mathrm{NO}_{x}$ emissions ranged from 1.7 to $3.3 \mathrm{~g} \mathrm{NO}_{2} / \mathrm{kg}$ fuel. Data are presented for three combustion air flowrates at inlet air temperatures from 850 to $900 \mathrm{~K}$. Pressure ranged from $1.3 \times 10^{5} \mathrm{~Pa}$ at $2.8 \mathrm{~g} / \mathrm{s}$ to $2.0 \times 10^{5} \mathrm{~Pa}$ at $5.1 \mathrm{~g} / \mathrm{s}$. The program $\mathrm{NO}_{\mathrm{x}}$ emission goal of $3.7 \mathrm{~g} \mathrm{NO}_{2} / \mathrm{kg}$ fuel is shown for comparison. It is based on a proposed standard of $0.4 \mathrm{~g} \mathrm{NO} / \mathrm{mile}$ and was calculated using the density of diesel no. 2 fuel and a steady state fuel economy of $30 \mathrm{miles} / \mathrm{gallion}$. All measured $\mathrm{NO}_{\mathrm{x}}$ emissions are below the program goal. From Fig. 4, the $\mathrm{NO}_{\mathrm{x}}$ emission index decreased with equivalence ratio. $\mathrm{NO}_{x}$ concentration levels in parts per 
million increased slightly with equivalence ratio. Data are shown for cooling air flowrates of 3.5 and $5.9 \mathrm{~g} / \mathrm{s}$. At a constant cooling air flowrate, NOx emissions increased as the combustion air flowrate increased. Less heat was removed as a percentage of that available at the increased combustion air flowrates and the temperature of the system increased. This would be expected to increase $\mathrm{NO}_{x}$ emissions. Pressure was also increased at the increased combustion air flowrates which would also tend to increase $\mathrm{NO}_{\mathrm{X}}$ emissions. Little effect of cooling air flowrate, however, was shown on NOx emissions at a combustion air flowrate of $2.8 \mathrm{~g} / \mathrm{s}$. For this combustion air flowrate, at an equivalence ratio of 0.88 , cooling air flowrates of 5.9 and $3.5 \mathrm{~g} / \mathrm{s}$ produced exit temperatures of 1352 and $1420 \mathrm{~K}$, respectively. Little measureable difference in NO, emissions would be expected at these relatively low temperatures for a difference of $68 \mathrm{~K}$.

The effect of equivalence ratio on $\mathrm{CO}$ emissions is presented in Fig. 5. CO emissions are presented as an emission index, $g$ Co/kg fuel, for equivalence ratios ranging from 0.55 to 90 . Data are presented for the identical flowrates as in Fig. 4. A CO emission program goal of $32.0 \mathrm{~g} \mathrm{CO} / \mathrm{kg}$ fuel is shown for comparison. It is based on a proposed standard of $3.4 \mathrm{~g} \mathrm{CO/mile}$ and was again calculated using the density of diesel no. 2 fuel and a fuel economy of $30 \mathrm{miles} / \mathrm{gall}$ on. The $\mathrm{CO}$ emission index ranged from 0.3 to $2.7 \mathrm{~g} \mathrm{CO} / \mathrm{kg}$ fuel and was well below the program goal. CO emissions generally decreased with equivalence ratio until about 0.75 or 0.8 and then increased. For a constant cooling air flowrate of $5.9 \mathrm{~g} / \mathrm{s}$, CO emissions decreased with increasing combustion air flowrate. At the higher combustion air flowrate, system temperatures were increased and pressure was also slightly higher, both of which tend to increase reaction rates and reduce $\mathrm{CO}$ emissions. At a combustion air flowrate of $2.8 \mathrm{~g} / \mathrm{s}$, little effect of cooling air flowrate is shown at an equivalence ratio of 0.88 , however, a small effect is shown at an equivalence ratio of 0.75 . This could be attributed to data scatter at these very small values since there is a difference of only $20 \mathrm{ppm}$. Calculated equilibrium values of $\mathrm{CO}$ at the average exit temperature ranged 
from about $1 \times 10^{-3}$ to $2 \times 10^{-2}$ g co/ $/ \mathrm{kg}$ fue 1 for the equivalence ratios and exit temperatures of this study. Equilibrium CO increased with both equivalence ratio and exit temperature. Even though measured $\mathrm{CO}$ emissions were above the equilibrium values, they were still very low. Combustion efficiencies greater than 99.5 percent were measured for all data points shown in Fig. 5 .

No data are presented for unburned hydrocarbons emissons. They were extremely low at the fairly high inlet air temperatures used for this study for combustion products exit temperatures greater than approximately $1250 \mathrm{~K}$. At exit temperatures below $1250 \mathrm{~K}$, combustion efficiency decreased rapidly and unburned hydrocarbons emissions increased. Axial temperature profile of the system is presented in Fig. 6. Temperatures of the combustion gas, heat exchanger plate, and cooling air are shown for a combustion air flowrate of $2.8 \mathrm{~g} / \mathrm{s}$ and an equivalence ratio of 0.9 . The combustion efficiency was 99.88 percent. Combustion gas temperatures are shown for both flow passages. As shown in Fig. 6, the inlet air temperature was $900 \mathrm{~K}$. At a distance $2.5 \mathrm{~cm}$ downstream of the leading edge of the plates, the average combustion gas temperature in the passages was $1200 \mathrm{~K}$. The combustion gas temperature increased to an average of $1435 \mathrm{~K}$ at a distance $7.5 \mathrm{~cm}$ downstream of the plate inlet. The temperature of the combustion products remained essentially constant from $7.5 \mathrm{~cm}$ downstream to the measured exit temperature at $13.5 \mathrm{~cm}$ downstream. Heat exchanger plate wall temperature increased 1 inearly from $1090 \mathrm{~K}$ at $1.2 \mathrm{~cm}$ downstream to $1165 \mathrm{~K}$ at $8.7 \mathrm{~cm}$ from the leading edge. Cooling air temperatures, measured only at the inlet and exit, were 290 and $880 \mathrm{~K}$, respectively. The larger temperature difference between the heat exchanger plate wall and the cooling air as compared to the combustion gas and the heat exchanger plate wall indicates that the cooling air heat transfer coefficient is smaller than the combustion side coefficient and was the limiting heat transfer coefficient for this case.

HEAT FLUX - Heat flux, as a function of the fuel flowrate in $W / \mathrm{cm}^{2}$, is presented in Fig. 7. The parameter is based on the side exposed heat exchanger plate surface area, 
$206.5 \mathrm{~cm}^{2}$. Data are shown for three combustion air flowrates at inlet air temperatures from 850 to $900 \mathrm{k}$. Pressure ranged from $1.3 \times 10^{5}$ to $2.0 \times 10^{5} \mathrm{~Pa}$. The cooling air flowrate was held constant at $5.9 \mathrm{~g} / \mathrm{s}$. Heat flux available from the fuel is shown. As shown in Fig. 7 , heat flux to the cooling air ranged from about 11 to $15 \mathrm{~W} / \mathrm{cm}^{2}$. At a fuel flowrate of $0.1 \mathrm{~g} / \mathrm{s}, 44$ percent of the heat available from the fuel was transferred to the cooling air. Another 20 percent of the heat available from the fuel remained in the combustion products. Heat flux to the combustion products was based on the increase in combustion gas temperature from the in let to the exit and does not include the sensible preheat of the combustion air. About 40 percent of the heat available from the fuel was lost from the system as heat losses. More insulation would decrease this loss. However, at the relatively low flowrates used for this study, heat losses are expected to remain fairly large. In an engine application, a configuration utilizing this concept would probably consist of a circular arrangement of alternating heat exchanger and catalytic plates and heat losses could be kept to a minimum, since the heat loss from the side would be eliminated.

For this study, the heat exchanger plate wall temperature was maintained at approximately the heater tube temperature of the P40 Stirling engine, $1000-1200 \mathrm{~K}$. The P40 Stirling engine uses high pressure hydrogen as the working fluid which has a very high convective heat transfer coefficient. The bulk temperature of the hydrogen is only a few degrees less than the heater tube wall temperature. Utilizing hydrogen as a coolant in the heat exchanger plates could increase the heat transferred to the coolant. It would be necessary, however, to design the system such that the wall temperature be kept at current levels. Too much heat cannot be extracted, however, or the combustion reactions will be quenched and poor combustion efficiencies will result. If gas phase reactions in the passages are not initiated, which quickly completes the combustion reactions, and only surface reactions are occurring on the catalytic surface, combustion efficiency will be relatively poor since not enough surface area is available for complete conversion of the fuel. If heat losses could 
be eliminated and that heat transferred to the coolant, about 80 percent of the heat available from the fuel could be transferred to the coolant at a fuel flowrate of $0.1 \mathrm{~g} / \mathrm{s}$. Since combustion efficiency was greater than 99.5 percent for all points shown in Fig. 7, combustion efficiency could be maintained at this level since total heat removed from the combustion reactions would be unchanged. As previously discussed, the exit temperature of the combustion products must be approximately $1250 \mathrm{~K}$ or above, to maintain combustion efficiences of at least 99.5 percent.

Heat flux to the cooling air as a function of the equivalence ratio is presented in Fig. 8. Heat flux in $W / \mathrm{cm}^{2}$, based on $206.5 \mathrm{~cm}^{2}$ of heat exchanger surface area, is presented for equivalence ratios ranging from 0.5 to 0.9 . At a cooling air flowrate of $5.9 \mathrm{~g} / \mathrm{s}$, data are presented for three combustion air flowrates. At an equivalence ratio of 0.8 , increasing the combustion air flowrate from 2.8 to $5.1 \mathrm{~g} / \mathrm{s}$ increased the heat flux to the cooling air from 12.7 to $15.7 \mathrm{~W} / \mathrm{cm}^{2}$. At the increased combustion air flowrates, more heat is available and convective heat transfer coefficients are also increased. At a combustion air flowrate of $2.8 \mathrm{~g} / \mathrm{s}$, the effect of cooling air flowrate is shown. At an equivalence ratio of 0.89 , increasing the cooling air flowrate from 3.5 to $5.9 \mathrm{~g} / \mathrm{s}$ increased the heat flux to the cooling air from 11 to $13.3 \mathrm{~W} / \mathrm{cm}^{2}$. As shown in Fig. 8, increasing the cooling air flowrate had a decreasing effect on the increase in heat transferred to the cooling air. At increasing cooling air flowrates, the convective heat transfer coefficient was increased, however, heat exchanger plate wall temperature decreased. Heat exchanger plate wa11 temperature ranged from about 1000 to 1200 K. Combustion products exit temperature ranged from about 1240 to $1500 \mathrm{~K}$. The system demonstrated very stable operation at equivalence ratios up to 0.9 . For all data points shown, combustion efficiency was greater than 99.5 percent.

\section{SUMMARY OR RESULTS}

This study has demonstrated that the parallel plate catalytic combustor with heat removal is capable of achieving high combus- 
tion efficiencies and relatively low thermal $\mathrm{NO}_{x}$ emission at equivalence ratios up to 0.9. The configuration utilized spaced parallel plates with alternating catalytic and heat exchanger plates. Combustion efficiencies of 99.5 percent and above were measured. $\mathrm{NO}_{\mathrm{x}}$ emissions ranged from 1.85 to $3.6 \mathrm{~g} \mathrm{NO} / \mathrm{kg}$ fuel and were below the program goai of $3.7 \mathrm{~g} \mathrm{NO}_{2} / \mathrm{kg}$ fuel. Very stable combustion and operation of the system was obtained at equivalence ratios from 0.5 to 0.9. At combustion efficiences of 99.5 percent and above, exit temperature of the combustion products ranged from about 1250 to $1500 \mathrm{~K}$. This is higher than the exit gas temperature of $1010 \mathrm{~K}$ for the P40 Stirling engine. Thus, a second convective heat exchanger may be required in order to reduce the temperature of the combustion products to this level and extract additional heat.

Further investigation of the concept is warranted. From the results obtained, it appears that approximately 80 percent of the heat available from the fuel can be removed while maintaining high combustion efficiency. The system was not optimized for plate spacing or length. A coolant which is a better approximation to the hydrogen in the Stirling engine should also be used. Finally, heat losses for this experimental configuration were significant, approximately 40 percent, and would be reduced in an engine application.

\section{REFERENCES}

1. W. R. Martini, "Stirling Engine Design Manual," Joint Center for Graduate Study, NASA Grant NSG 3152, D0E Contract EC-77-A-31-1011. NASA CR-135382, DOE/NASA/3152-78/1, 1978.

2. J. E. Cairelli, and G. G. Kelm, "Emission Measurements from the P40 Stirling Engine," Presented at Automotive Technology Development Contractor Coordination Meeting, Dearborn, Michigan, October 1981, Prepared for U.S. Dept. of Energy under Interagency Agreement DEAI01-77CS51040.

3. R. G. Gabrielsson, and T. A. Lia, "Low Emission Combustor for Stirling Engines." In "Energy 10, Intersociety Energy Conversion Engineering Conference Record," New York: Institute of Electrical and Electronics Engineers, Inc., 1975, pp. 927-932. 
4. S. R. Davis, N. A. Henein, and R. R. Lundstrom, "Combustion and Emission Formation in the Stirling Engine with Exhaust Gas Recirculation," SAE Paper No. 710824, 1971.

5. W. C. Pfefferle, et. al., "Catathermal Combustion: A New Process for LowEmissions Fuel Conversion," ASME Paper 75-WA/FU-1, 1975.

6. D. N., "Emissions and Performance of a Catalytic Reactor with Propane, Diesel, and Jet A Fuels," NASA TM-73786, 1977.

7. J. P. Kesselring, et. al., "Design Criteria for Stationary Source Catalytic Combustion System." EPA-600/7-79-181, 1979.

8. D. L. Bulzan, "Experimental Evaluation of Catalytic Combustion with Heat Removal at Near Stoichiometric Conditions," NASA TM-81748, 1980.

9. "Procedure for the Continuous Sampling and Measurement of Gaseous Emissions for Aircraft Turbine Engine." Aerospace Recommended Practice. 1256, Society of Automotive Engineers, October 1, 1980.

10. S. Gordon, and B. J. McBride, "Computer Program for Calculation of Complex Chemical Equilibrium Compositions, Rocket Performance, Incident and Reflected Shocks, and Chapman-Jouquet Detonations." NASA SP-273, Revised 1976. 


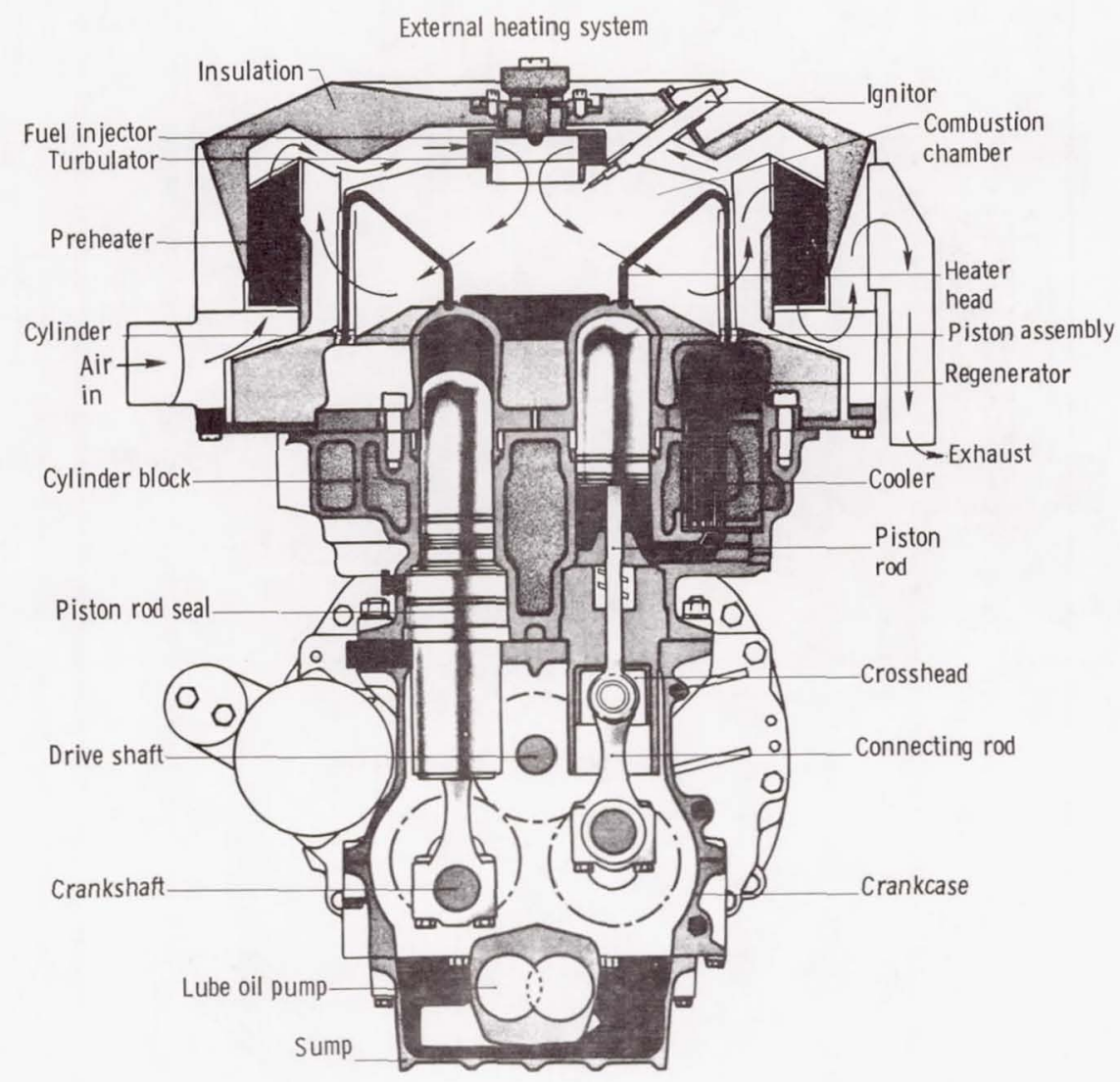

(a) CROSS SECTION OF UNITED STIRLING P4O (4-95) ENGINE.

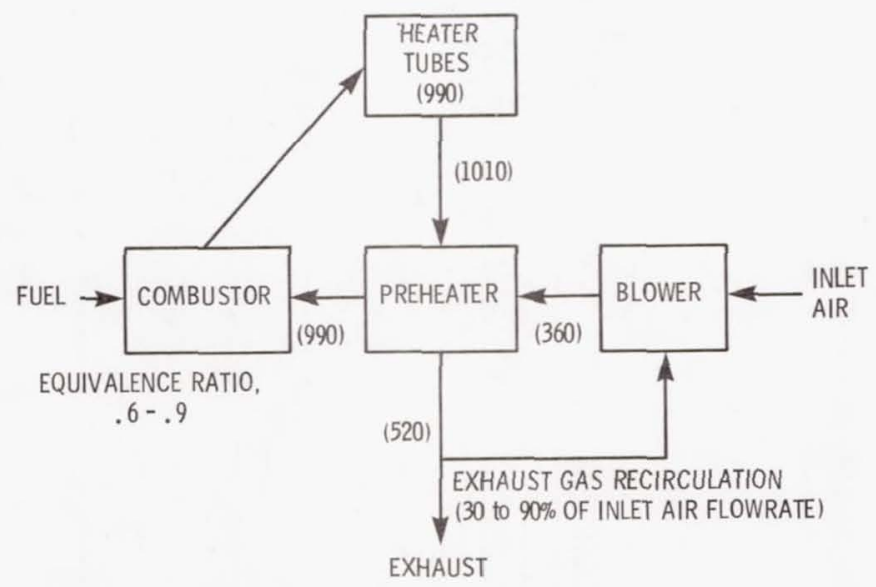

(b) P4O STIRLING ENGINE COMBUSTION SYSTEM SCHEMATIC (AVERAGE TEMPERATURES SHOWN IN K).

Figure 1. 


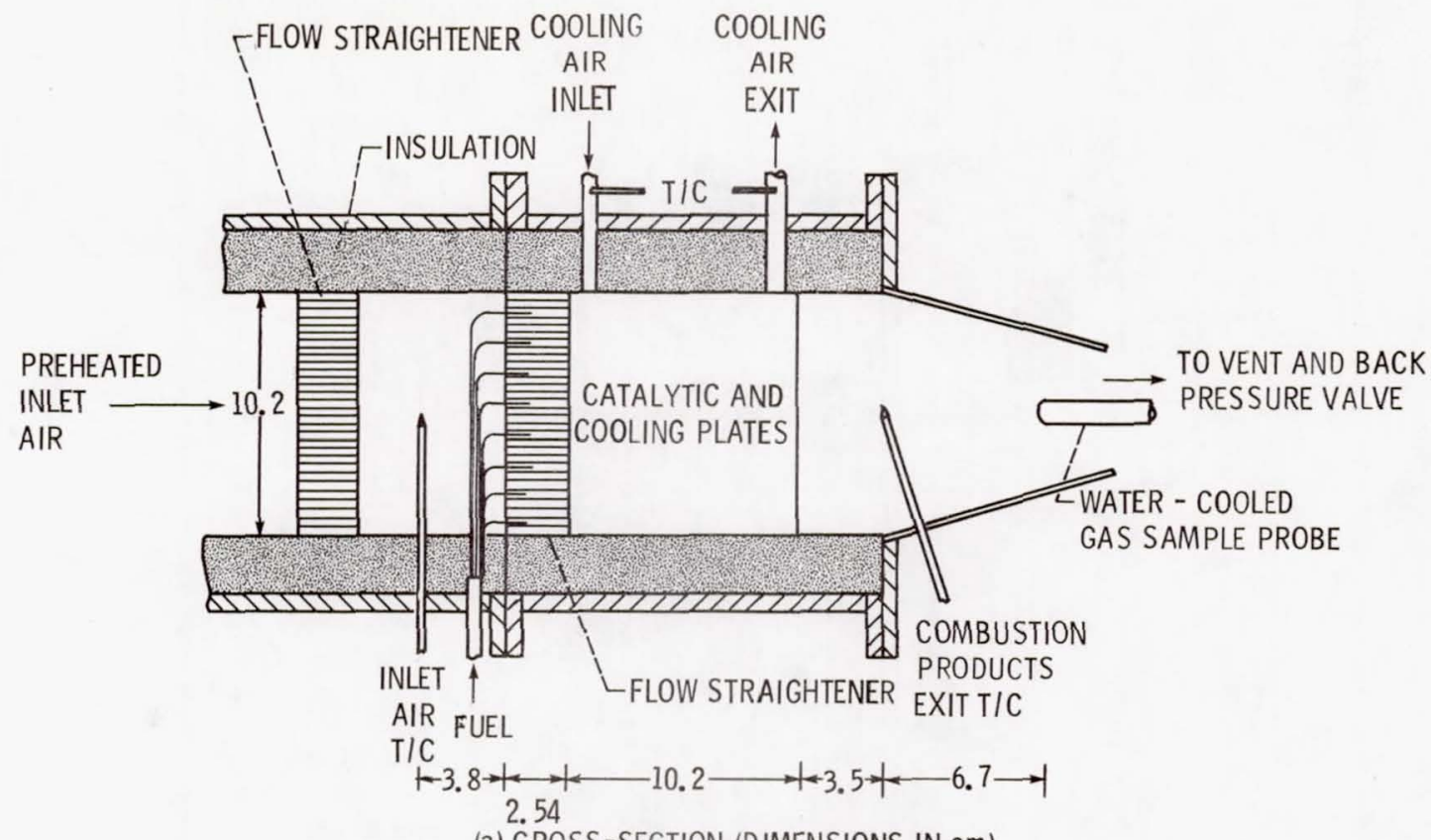

(a) CROSS-SECTION (DIMENSIONS IN cm).

Figure 2. - Test rig schematic.

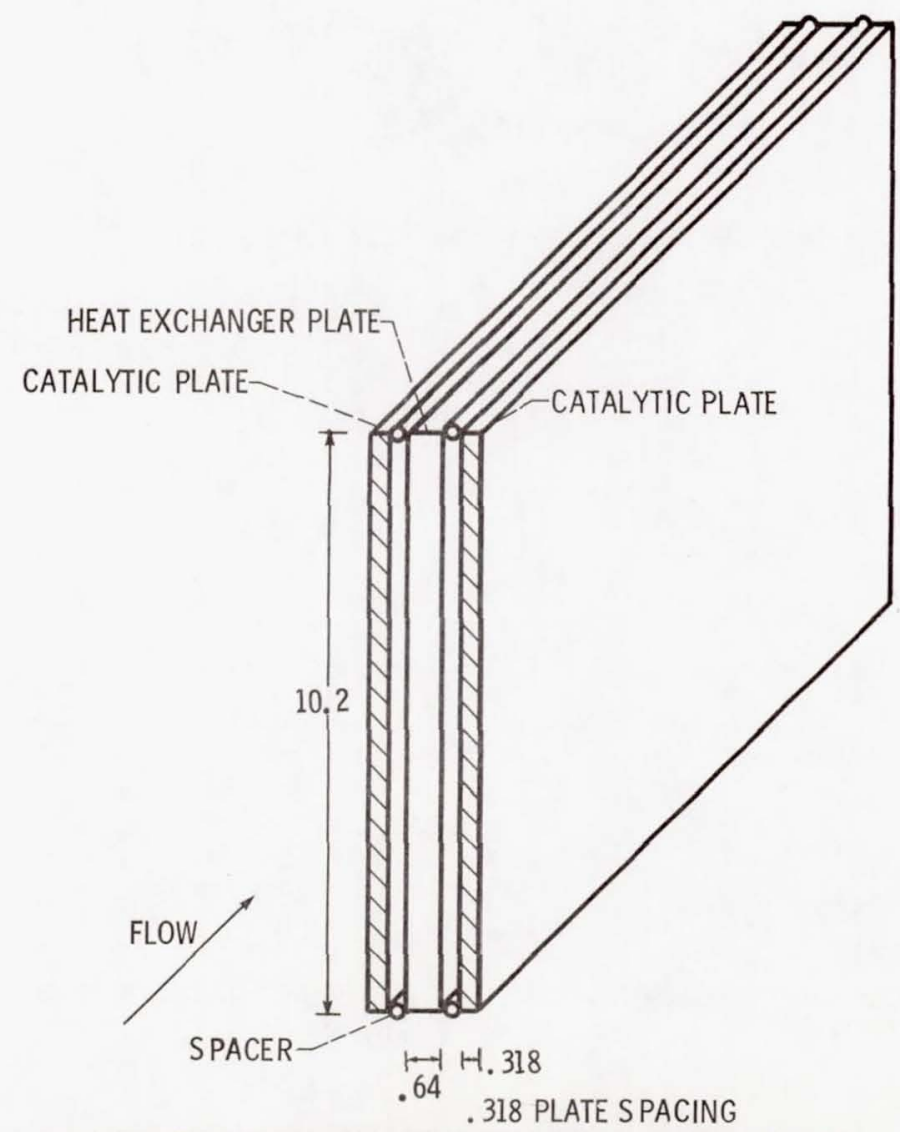

(b) PLATE FRONT FACE ARRANGEMENT (LOOKING DOWNSTREAM).

Figure 2. - Concluded. 


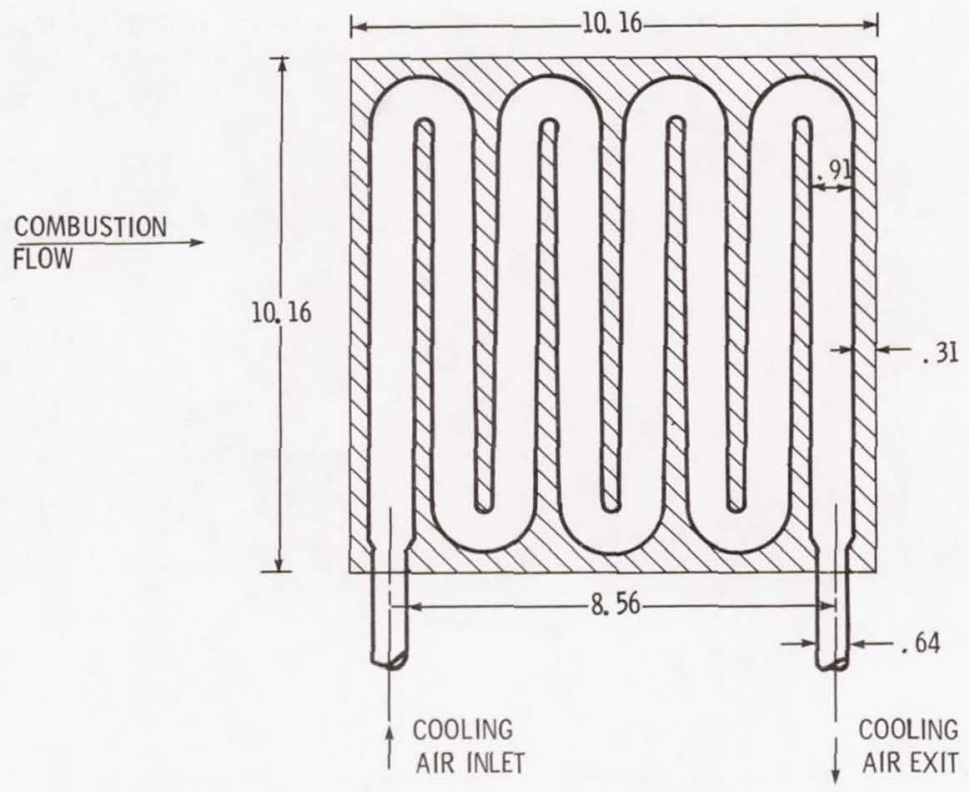

Figure 3. - Heat exchanger plate. (Dimensions in $\mathrm{cm}$.)

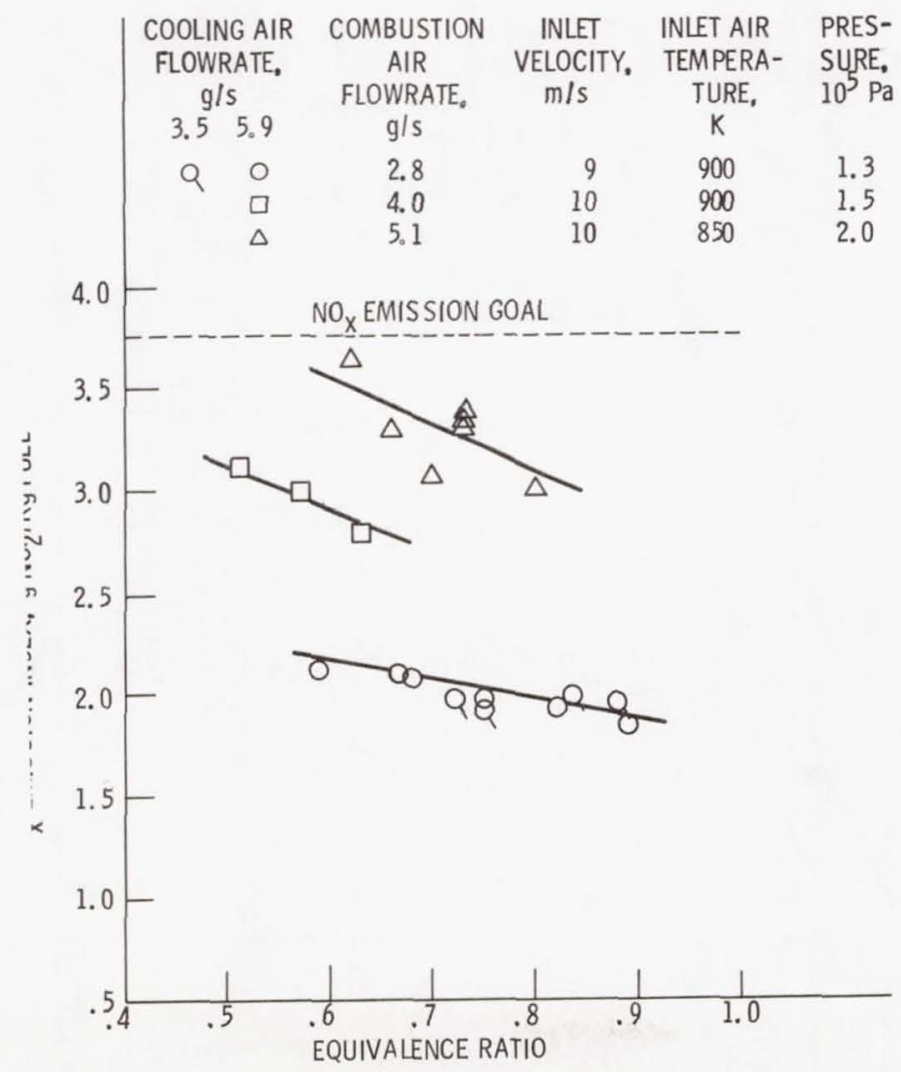

Figure 4. - $\mathrm{NO}_{x}$ emissions. 


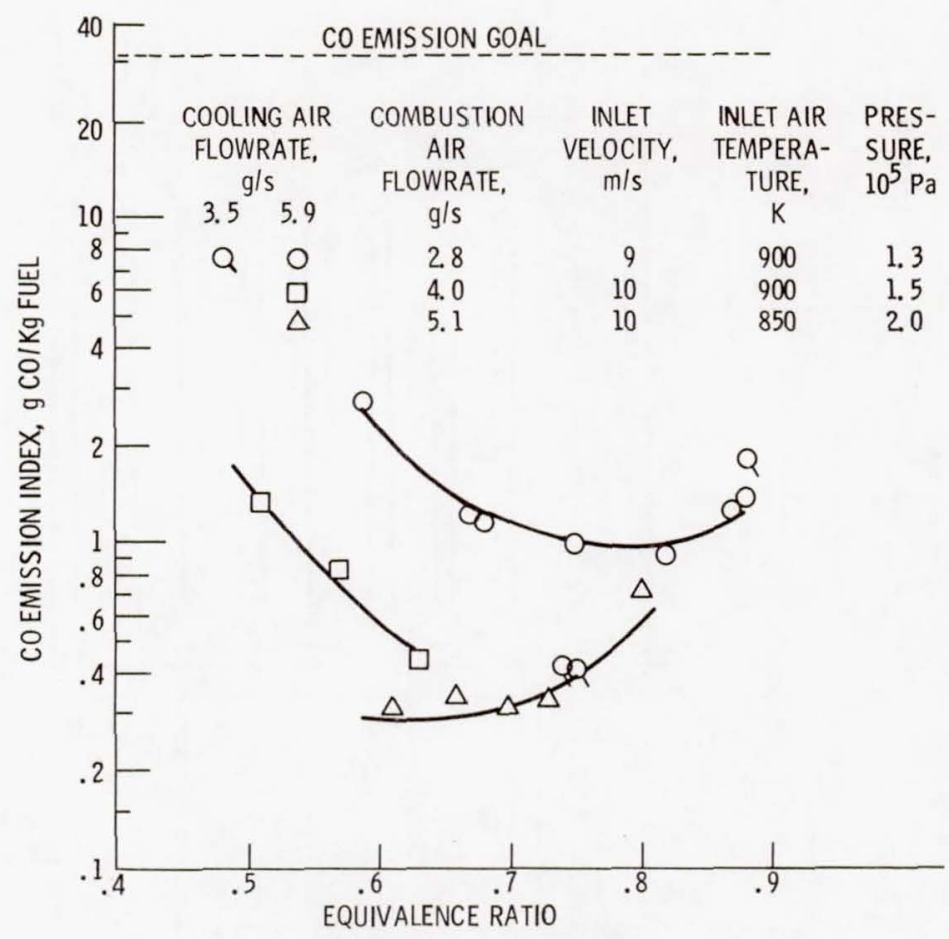

Figure 5. - $\mathrm{CO}$ emissions.

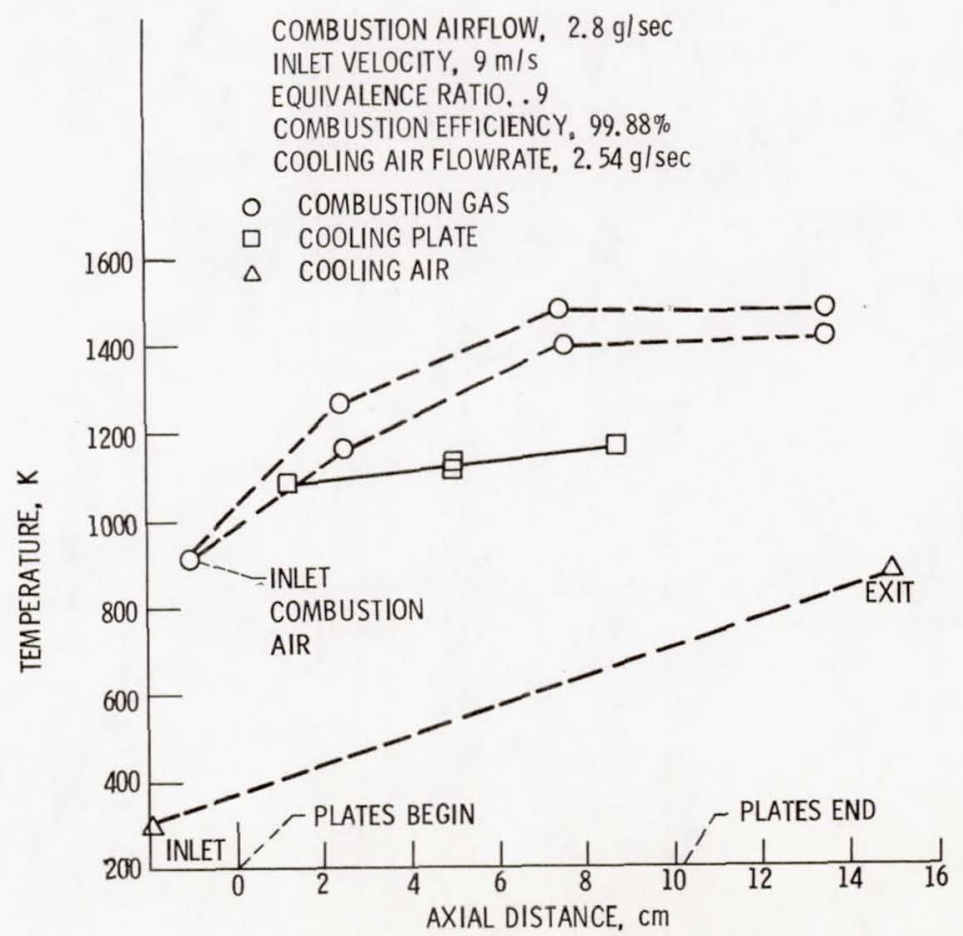

Figure 6. - Axial temperature profile. 


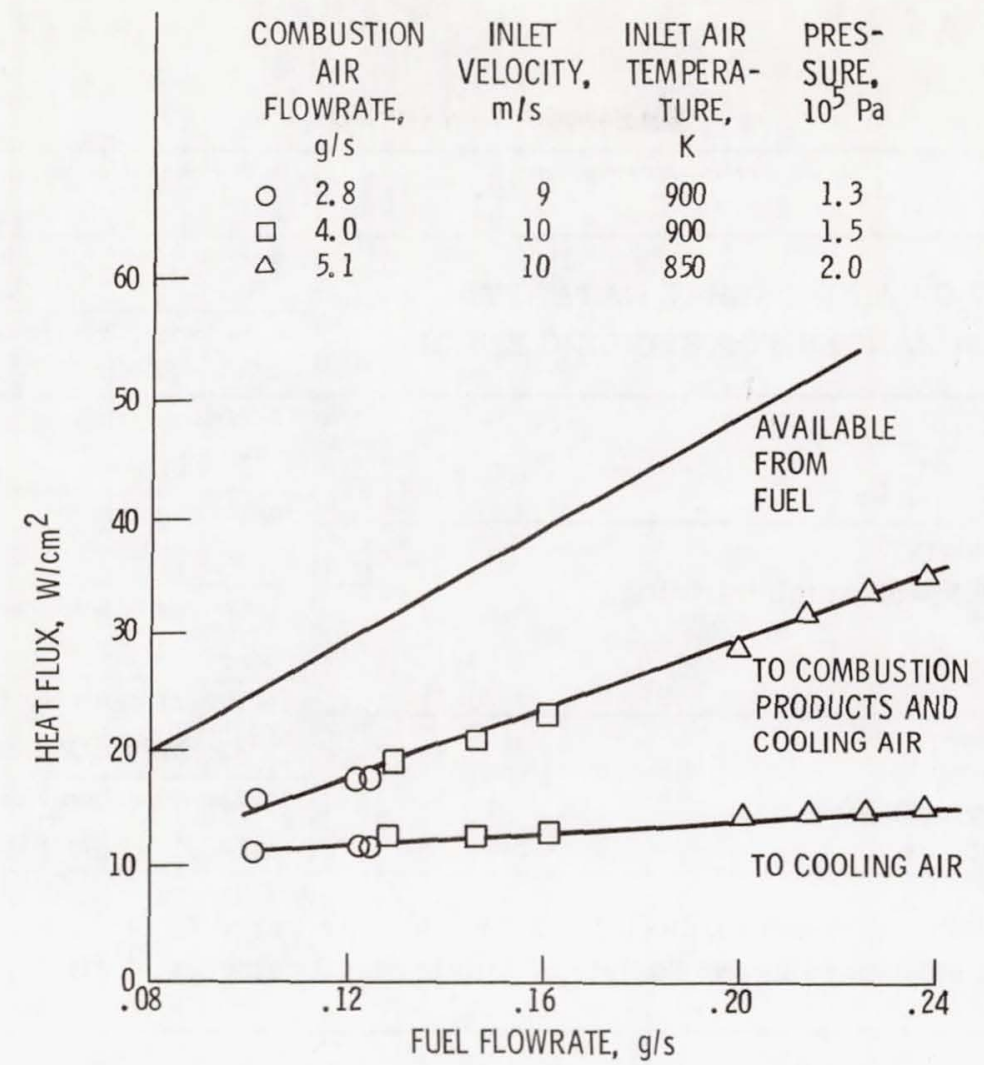

Figure 7. - Heat flux; cool ing air flowrate, $5.9 \mathrm{~g} / \mathrm{s}$.

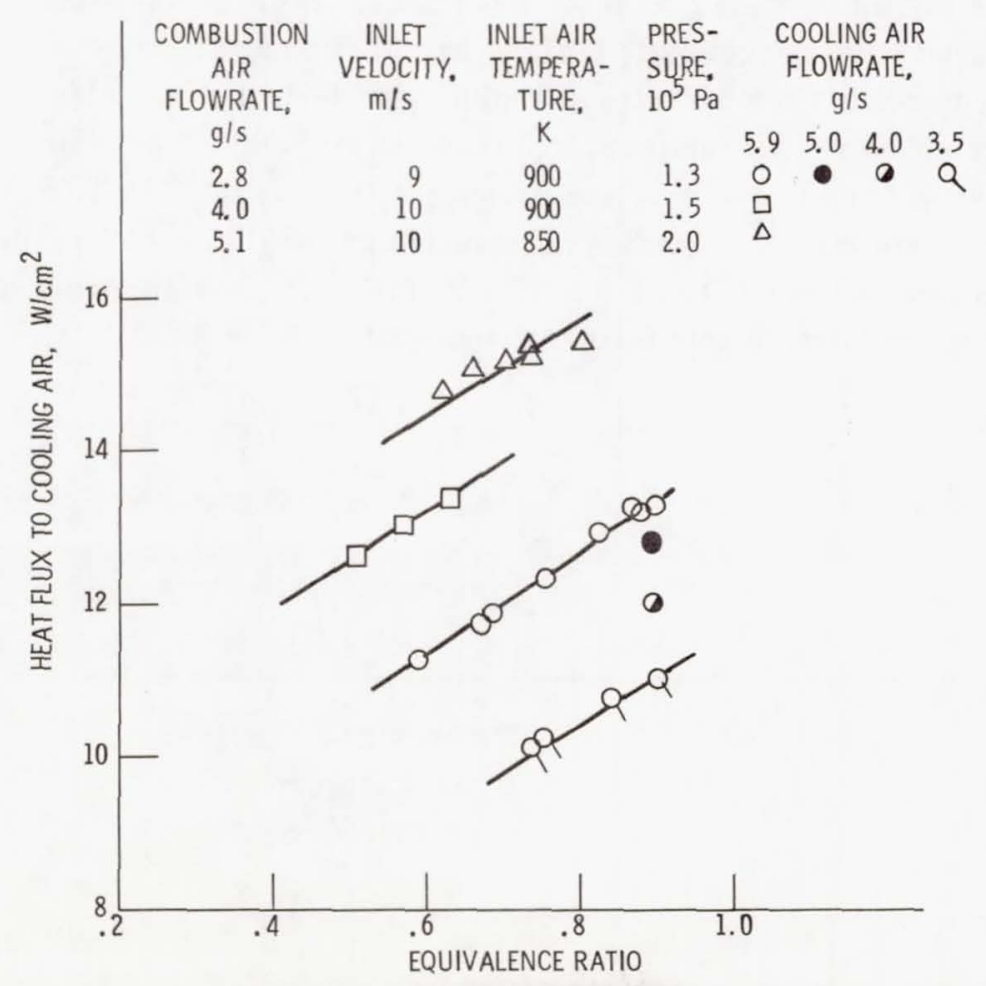

Figure 8. - Heat flux to cooling air. 


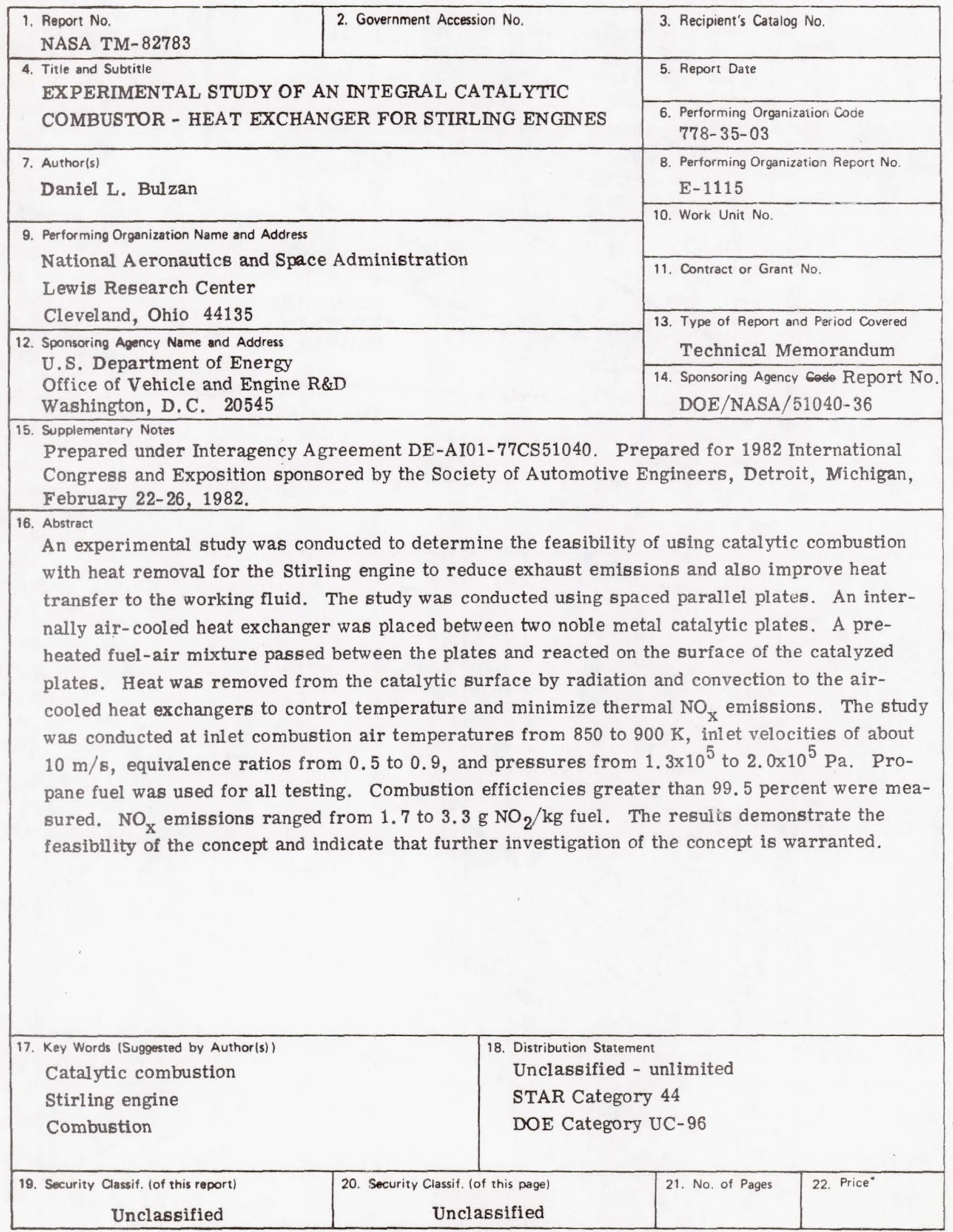

* For sale by the National Technical Information Service, Springfield, Virginia 22161 